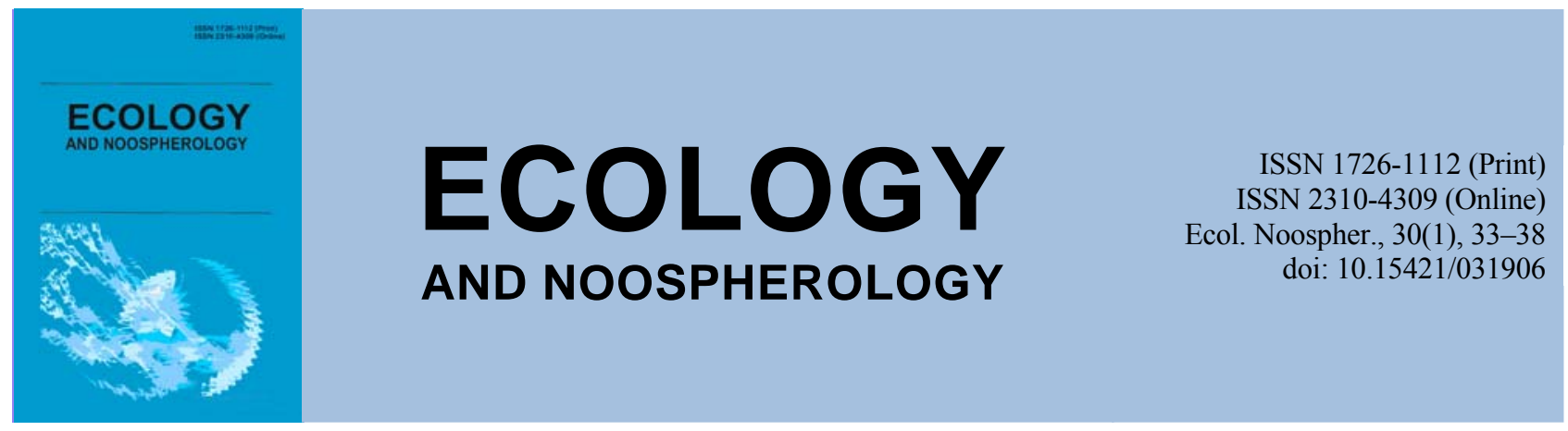

\title{
The effect of artificial forest plantations on the thermophysical properties of chernozems
}

\author{
V. A. Gorban \\ Oles Honchar Dnipro National University, Dnipro, Ukraine
}

Article info

Received 15.01.2019

Received in revised form

22.01.2019

Accepted 01.02.2019

Oles Honchar Dnipro

National University

Gagarin Ave., 72, Dnipro,

49010, Ukraine.

Tel.: +38-050-362-45-90

E-mail:vad01@ua.fm
Gorban, V. A. (2019). The effect of artificial forest plantations on the thermophysical properties of chernozems. Ecology and Noospherology, 30(1), 33-38. doi:10.15421/031906

As a result of a study of the effect of artificial forest plantations formed by Robinia pseudoacacia L. and Quercus robur L., on the thermophysical features of the chernozems of the Komissarovsky reserve (Pyatykhatsky district, Dnepropetrovsk region, Ukraine), it was found that the stand of robinia reduced air temperature by $4,5^{\circ} \mathrm{C}$, oak - by $9.4{ }^{\circ} \mathrm{C}$ in comparison with the open area. The maximum temperature of the soil surface is found in ordinary chernozem. The effect of robinia plantation manifested itself in the form of a decrease in the temperature of the soil surface by $5.4{ }^{\circ} \mathrm{C}$, and the oak surface by $8.0^{\circ} \mathrm{C}$. The maximum soil temperature at a depth of $50 \mathrm{~cm}$ is also found in ordinary chernozem. At the same depth, the soil under robinia plantation turned out to be $7.6{ }^{\circ} \mathrm{C}$, under oak $-6.9{ }^{\circ} \mathrm{C}$ colder. According to the average temperature of the 50 -centimeter layer of all the studied soils, ordinary chernozem is distinguished, the soils under the plantations almost do not differ according to this indicator. The smallest difference between the air temperature and the average temperature of the soil layer $0-50 \mathrm{~cm}$ was in the soil under oak plantation, the largest - in the soil under robinia plantation. The smallest difference between the temperature of the soil surface and at a depth of $50 \mathrm{~cm}$ was found in the soil under oak plantation, and the greatest difference in the soil under robinia plantations. Based on the analysis of the results obtained, an assumption was made about the thermal features of the upper horizons, which fall within the interval of 0-50 cm, of each of the three studied soils. The soil under robinia plantation is characterized by maximum values of thermal diffusivity, and ordinary chernozem - minimal. The soil under the oak plantation occupies an intermediate value for this indicator. Ordinary chernozem is characterized by maximum values of heat capacity, slightly smaller values are characteristic of soil for robinia plantations. The minimum values of heat capacity are characteristic of oak plantation soil. The soil under robinia plantation is sharply distinguished by the maximum values of thermal conductivity compared to ordinary chernozem and the soil under oak planting. The actual study of thermophysical properties confirmed the correctness of the assumption in only one of the three indicators for each of the studied soils. This indicates a significant limitation of predicting the thermophysical indicators of soils, based only on measuring their temperature. The influence of robinia plantation on the thermal physical properties of ordinary chernozems is manifested in an increase in their thermal diffusivity and thermal conductivity, as well as in a certain decrease in heat capacity. The influence of oak stands is characterized by an increase in thermal diffusivity and heat capacity, as well as a decrease in thermal conductivity of ordinary chernozem.

Keywords: temperature thermal diffusivity; heat capacity; thermal conductivity; Robinia pseudoacacia L.; Quercus robur L.

\section{Вплив штучних лісових насаджень на теплофізичні властивості чорноземів звичайних}

\author{
В. А. Горбань
}

Дніпровський національний університет імені Олеся Гончара, Дніпро, Україна

У результаті дослідження впливу штучних лісових насаджень, сформованих Robinia pseudoacacia L. тa Quercus robur L., на теплофізичні особливості чорноземів звичайних Комісарівського заказника (П'ятихатський р-н Дніпропетровської обл., 
Україна) було встановлено, що деревостан робінієвого насадження зменшив температуру повітря на $4,5{ }^{\circ} \mathrm{C}$, дубового - на $9,4{ }^{\circ} \mathrm{C}$ порівняно 3 відкритою місцевістю. Максимальну температуру поверхні грунту виявлено в чорноземі звичайному. Вплив робінієвого насадження проявився у вигляді зменшення температури поверхні грунту на $5,4{ }^{\circ} \mathrm{C}$, дубового - на $8,0{ }^{\circ} \mathrm{C}$. Максимальна температура грунту на глибині 50 см також виявлена в чорноземі звичайному. На такій самій глибині грунт під робінієвим насадженням виявився на $7,6{ }^{\circ} \mathrm{C}$, під дубовим - на $6,9{ }^{\circ} \mathrm{C}$ холоднішим. За середньою температурою 50-сантиметрового шару серед усіх досліджуваних грунтів виділяється чорнозем звичайний, грунти під насадженнями за цим показником майже не відрізняються. Найменша різниця між температурою повітря та середньою температурою шару грунту 0-50 см виявилася в грунті під дубовим насадженням, найбільша - у грунті під робінієвим насадженням. Найменшу різницю між температурою поверхні грунту та на глибині 50 см виявлено в грунті під дубовим насадженням, а найбільшу у грунті під робінієвим насадженням. На основі аналізу отриманих результатів було зроблено припущення щодо термічних особливостей верхніх горизонтів, які входять до інтервалу глибин 0-50 см, кожного 3 трьох досліджуваних грунтів. Фактичне дослідження теплофізичних властивостей підтвердило правильність припущення лише щодо одного 3 трьох показників для кожного 3 досліджуваних грунтів. Це свідчить про значну обмеженість прогнозування теплофізичних показників грунтів, які базуються лише на вимірюванні їх температури. Вплив робінієвого насадження на теплофізичні властивості чорноземів звичайних проявляється в збільшенні іх температуропровідності та теплопровідності, а також деякому зменшенні теплоємності. Вплив дубового насадження характеризується зростанням температуропровідності та теплоємності, а також зниженням теплопровідності чорноземів звичайних.

Ключові слова: температура; температуропровідність; теплоємність; теплопровідність; Robinia pseudoacacia L.; Quercus robur L.

\section{Вступ}

Грунт як специфічний фізичний об’єкт характеризується рядом своєрідних теплофізичних властивостей. Відповідно до робіт А. Ф. Вадюніної та 3. О. Корчагіної (Vadyunina, Korchagina, 1986), Ю. А. Созіна (Sozin, 1990), Ochsner et al. (2001), В. А. Горбаня (Gorban, 2006), В. А. Горбаня та А. А. Горбаня (Gorban V., Gorban A., 2007) до основних теплофізичних властивостей можна віднести теплоємність, температуропровідність та теплопровідність.

Для розуміння деяких особливостей теплових властивостей грунту наводимо їх визначення (за: Vadyunina, Korchagina, 1986). Об'ємна питома теплоємність - це кількість теплоти, яка необхідна для нагрівання $1 \mathrm{~m}^{3}$ сухого грунту на $1{ }^{\circ} \mathrm{C}$. Теплопровідність здатність грунту поглинати і проводити тепло в напрямку, протилежному термічному градієнту, тобто від гарячих шарів до холодних. Кількість теплової енергії, що передається через шар грунту, пропорційна градієнту температури i коефіцієнту теплопровідності. Температуропровідність - здатність грунту вирівнювати свою температуру при наявності різниці нагріву в даній та прилеглій точках.

Відомо, що теплові властивості грунту досліджують для визначення змін температури грунту в процесі поглинання тепла діяльною поверхнею та ії перерозподілу в активному шарі грунту (Makarova, 1987). При надходженні однакової кількості тепла зміна температури грунту визначається іiі теплоємністю, а інтенсивність внутрішньогрунтового перенесення тепла Температуропровідність відображає швидкість вирівнювання температур грунту. Ця швидкість визначається як теплопровідністю, так і теплоємністю грунту. Показника тільки однієї теплопровідності недостатньо для визначення швидкості нагрівання або охолодження грунту, оскільки в однакових зовнішніх умовах при близьких величинах теплопровідності більш теплоємні грунти будуть повільніше нагріватися i повільніше холонути. При вивченні температурного режиму грунту зручно використовувати показник температуропровідності, оскільки саме цей параметр характеризує «поширення» вимірюваної величини температури. Однак для аналізу механізмів явищ, що відбуваються, доводиться звертатися до понять теплопровідності і теплоємності (Teorii .., 2007). При дослідженні теплових властивостей грунту необхідно пам'ятати, що вони залежать від ряду інших характеристик грунту, таких як вміст органічних речовин, складання, механічний склад, вологість грунту і т. д. (Dimo, 1972; Ochsner et al., 2001; Abu-Hamdeh, 2003; Lukyashchenko, Arkhangelskaya, 2018).
Метою роботи є встановлення особливостей впливу штучних лісонасаджень на теплофізичні властивості чорноземів звичайних.

\section{Об’єкти та методи досліджень}

Для реалізації поставленої мети було закладено 3 пробні площі на території Комісарівського заказника, який розташований у межах П'ятихатського району Дніпропетровської області. Заказник розташований на південний захід від села Новоукраїнка і на північ від села Лозуватка. Комісарівський заказник знаходиться на території П'ятихатського лісництва (Верхньодніпровський держлісгосп, Дніпропетровське обласне управління лісового та мисливського господарства). Заказник розташований у верхів'ях балок Довжик та Тетяниної (ліві притоки р. Лозуватки) i на вододільному просторі між ними. На кожній пробній площі було закладено по грунтовому розрізу.

Перша пробна ділянка закладена на ділянці агроценозу, грунтовий покрив якого під час відбору грунтових зразків був вільний від рослинного покриву.

Макроморфологічна характеристика трунтового профілю

Нор 0-10 см Перегнійно-акумулятивний, орний, темно-сірий, сухий, грудкуватий, суглинковий, пухкий, корененасичений, у верхній частині заорані залишки трав'янистої рослинності. Перехід поступовий за кількістю коренів та щільністю.

H1 10-23 см Гумусовий, темно-сірий, сухуватий, грудкуватий, суглинковий, більш щільний, ніж попередній, корененасиченість менша, ніж у попередньому. Перехід поступовий за щільністю та забарвленням.

Н2 23-35 см Гумусовий, темно-сірий, сухуватий, грудкуватий, суглинковий, більш щільний за попередній, корені практично відсутні. Перехід різкий за щільністю та забарвленням.

HPk 35-81 см Перехідний, сірий 3 палевим відтінком, сухуватий, грудкуватий, суглинковий, щільний. Перехід поступовий за забарвленням. Закипання $372 \mathrm{~cm}$.

Pk 81-150 см Грунтоутворююча порода - лесоподібний суглинок палевого кольору з включенням білозірки.

Грунт - чорнозем звичайний середньовилугований середньогумусовий середньосуглинковий на лесоподібних суглинках.

Друга пробна ділянка закладена в насадженні Robinia pseudoacacia L.

Макроморфологічна характеристика трунтового профілю

Н1 0-10 см Перегнійно-акумулятивний, темно-сірий, сухий, дрібногрудкуватий, суглинковий, пухкий, багато коренів деревної рослинності. Перехід поступовий за кількістю коренів та щільністю.

Н2 10-38 см Гумусовий, темно-сірий, сухий, грудкуватий, суглинковий, більш щільний, ніж попередній, коренів менше, однак вони товстіші, ніж у попередньому. Перехід поступовий за забарвленням. 
Нр 38-57 см Перехідний, сірий, сухуватий, грудкуватий, суглинковий, щільний, зустрічаються окремі корені. Перехід різкий за забарвленням.

Phk 57-78 см Світло-сірий з палевим відтінком, сухуватий, грудкуватий, суглинковий, щільний, зустрічаються окремі товсті корені. Перехід поступовий за забарвленням. Закипання з $66 \mathrm{~cm}$.

$\mathrm{Pk}$ 78-150 см Грунтоутворююча порода - лесоподібний суглинок палевого кольору з включенням білозірки.

Грунт - чорнозем звичайний лісопокращений середньовилугований середньогумусовий середньосуглинковий на лесоподібних суглинках.

Третя пробна ділянка закладена в насадженні Quercus robur $\mathrm{L}$.

Макроморфологічна характеристика трунтового профілю

Н1 0-12 см Перегнійно-акумулятивний, темно-сірий, сухий, дрібногрудкуватий, суглинковий, пухкий, багато дрібних коренів трав'янистої рослинності. Перехід поступовий за кількістю коренів, щільністю та забарвленням.

Н2 12-44 см Гумусовий, темно-сірий, сухий, грудкуватий, суглинковий, більш щільний, ніж попередній. Перехід поступовий за забарвленням.

Нp 44-65 см Перехідний, сірий, сухуватий, грудкуватий, суглинковий, щільний, зустрічаються окремі корені. Перехід різкий за забарвленням.

Phk 65-87 см Світло-сірий з палевим відтінком, сухуватий, грудкуватий, суглинковий, щільний. Перехід поступовий за забарвленням. Закипання з $75 \mathrm{~cm}$.

$\mathrm{Pk}$ 87-150 см Грунтоутворююча порода - лесоподібний суглинок палевого кольору з включенням білозірки.

Грунт - чорнозем звичайний лісопокращений середньовилугований середньогумусовий середньосуглинковий на лесоподібних суглинках.

Вимірювання температури повітря виконували за допомогою цифрового анемометру-термометру-вологоміру Starmeter (ST8021).

Визначення температури грунту (на поверхні грунту (0 см) та глибинах 5, 10, 15, 20, 25, 30, 35, 40 та 50 см) виконували за допомогою набору температурних датчиків. Десять датчиків поміщали в попередньо підготовлену буром свердловину глибиною приблизно 52 см. Термодатчики за допомогою спеціально розробленого A. А. Горбанем додатку через Bluetooth поєднувалися зі смартфоном, передаючи йому цифрову інформацію щодо виміряної температури грунту.

Встановлення теплофізичних властивостей грунтів (температуропровідність, теплоємність та теплопровідність) виконували методом імпульсного нагрівання (Vadyunina, Korchagina, 1986; Sozin, 1990), який найчастіше використовується для таких досліджень (Bristow et al., 1994; Abu-Hamdeh, Reeder, 2000; Bachmann et al., 2001). Дослідження виконували 3 використанням установки та програмного забезпечення, розроблених В. А. Горбанем та А. А. Горбанем (Gorban V., Gorban A., 2007).

\section{Результати та їх обговорення}

Польові виміри температури грунту (шар 0-50 см) в літній період 2018 р. дали змогу отримати результати, які наведено на рис. 1. У результаті додаткового вимірювання температури повітря було отримано та розраховано ряд показників, які представлені в табл. 1. Аналіз представлених даних виявив, що найбільша температура повітря характерна для відкритої місцевості. Деревостан робінієвого насадження зменшив температуру повітря на 4,5 ${ }^{\circ} \mathrm{C}$, дубового - на $9,4{ }^{\circ} \mathrm{C}$ порівняно 3 відкритою місцевістю.

Максимальну температуру поверхні грунту також цілком закономірно виявлено в чорноземах звичайних. Вплив робінієвого насадження проявився у вигляді зменшення температури поверхні грунту на $5,4{ }^{\circ} \mathrm{C}$, дубового - на $8,0{ }^{\circ} \mathrm{C}$. Отримані результати повністю узгоджуються 3 даними, які свідчать про найбільшу середовищеперетворюючу роль у степових умовах деревних порід, що формують тіньову світлову структуру (Belgard, 1971; Hrytsan, 2000; Travleyev, Belova, 2008;
Ivanko, 2016). Максимальна температура грунту на глибині 50 см також виявлена в чорноземі звичайному. На такій самій глибині грунт під робінієвим насадженням виявився на $7,6{ }^{\circ} \mathrm{C}$, під дубовим - на $6,9{ }^{\circ} \mathrm{C}$ холоднішим. За середньою температурою 50-сантиметрового шару серед усіх досліджуваних грунтів виділяється чорнозем звичайний, грунти під насадженнями за цим показником майже не відрізняються. Найменша різниця між температурою повітря та середньою температурою шару грунту 0-50 см виявилася в грунтах під дубовим насадженням, найбільша - у грунтах під робінієвим насадженням.

\section{Таблиця 1}

Температурні показники повітря та досліджуваних грунтів (29.08.2018 p.)

\begin{tabular}{|c|c|c|}
\hline $\begin{array}{c}\text { Пробна площа 1- } \\
\text { зональний } \\
\text { чорнозем } \\
\text { звичайний }\end{array}$ & $\begin{array}{c}\text { Пробна площа } 2- \\
\text { чорнозем } \\
\text { звичайний } \\
\text { лісопокращений } \\
\text { під насадженням } \\
\text { Robinia } \\
\text { pseudoacacia } \mathrm{L} .\end{array}$ & $\begin{array}{c}\text { Пробна площа } 3 \text { - } \\
\text { чорнозем } \\
\text { звичайний } \\
\text { лісопокращений } \\
\text { під насадженням } \\
\text { Quercus robur L. }\end{array}$ \\
\hline \multicolumn{3}{|c|}{ Температура повітря, ${ }^{\circ} \mathrm{C}$} \\
\hline 36,8 & 32,3 & 27,4 \\
\hline \multicolumn{3}{|c|}{ Температура поверхні грунту, ${ }^{\circ} \mathrm{C}$} \\
\hline 35,2 & 29,8 & 27,2 \\
\hline \multicolumn{3}{|c|}{ Температура грунту на глибині $50 \mathrm{~cm},{ }^{\circ} \mathrm{C}$} \\
\hline 29,4 & 21,8 & 22,5 \\
\hline \multicolumn{3}{|c|}{ Середня температура шару грунту $0-50 \mathrm{~cm},{ }^{\circ} \mathrm{C}$} \\
\hline 31,8 & 24,6 & 24,8 \\
\hline \multicolumn{3}{|c|}{$\begin{array}{c}\text { Різниця між температурою повітря } \\
\text { та середньою температурою грунту, }{ }^{\circ} \mathrm{C}\end{array}$} \\
\hline 5,0 & 7,7 & 2,6 \\
\hline \multicolumn{3}{|c|}{ Різниця між температурою поверхні грунту } \\
\hline \multicolumn{3}{|c|}{ та на глибині 50 cм } \\
\hline 5,8 & 8,0 & 4,7 \\
\hline
\end{tabular}

Одним 3 найбільш важливих температурних показників, який у значній мірі відображає особливості теплофізичних властивостей гумусово-акумулятивних та перехідних генетичних горизонтів грунтів, $\epsilon$ різниця між температурою поверхні грунту та на глибині 50 см. За цим показником найменша різниця виявлена в грунті під дубовим насадженням, а найбільша - у грунті під робінієвим насадженням. Ураховуючи визначення теплофізичних властивостей грунтів, які наведено вище, отримані результати дають змогу зробити такі припущення щодо термічних особливостей верхніх горизонтів досліджуваних грунтів, які входять до інтервалу глибин 0-50 см. Для грунту під робінієвим насадженням повинні бути притаманні, внаслідок найбільшої різниці температур, найбільші значення теплоємності та відносно невеликі значення температуропровідності та теплоємності. Грунт під дубовим насадженням повинен характеризуватися, внаслідок мінімальної різниці температур, мінімальними значеннями теплоємності та збільшеними величинами температуропровідності та теплопровідності. Чорнозем звичайний повинен відрізнятися відносно середніми показниками досліджуваних теплофізичних властивостей.

Для перевірки зроблених припущень було виконано визначення теплофізичних властивостей досліджуваних грунтів, результати якого наведено в табл. 2.

Розрахунок середніх значень визначених теплофізичних властивостей за всім грунтовим профілем взагалі та окремо для перших трьох генетичних горизонтів кожного 3 досліджуваних грунтів виявив, що грунт під робінієвим насадженням характеризується максимальними величинами температуропровідності (середнє значення за трьома горизонтами $-7,356 \times 10^{-7} \mathrm{~m}^{2} / \mathrm{c}$, за грунтовим профілем - 
Температура, ${ }^{\circ} \mathrm{C}$

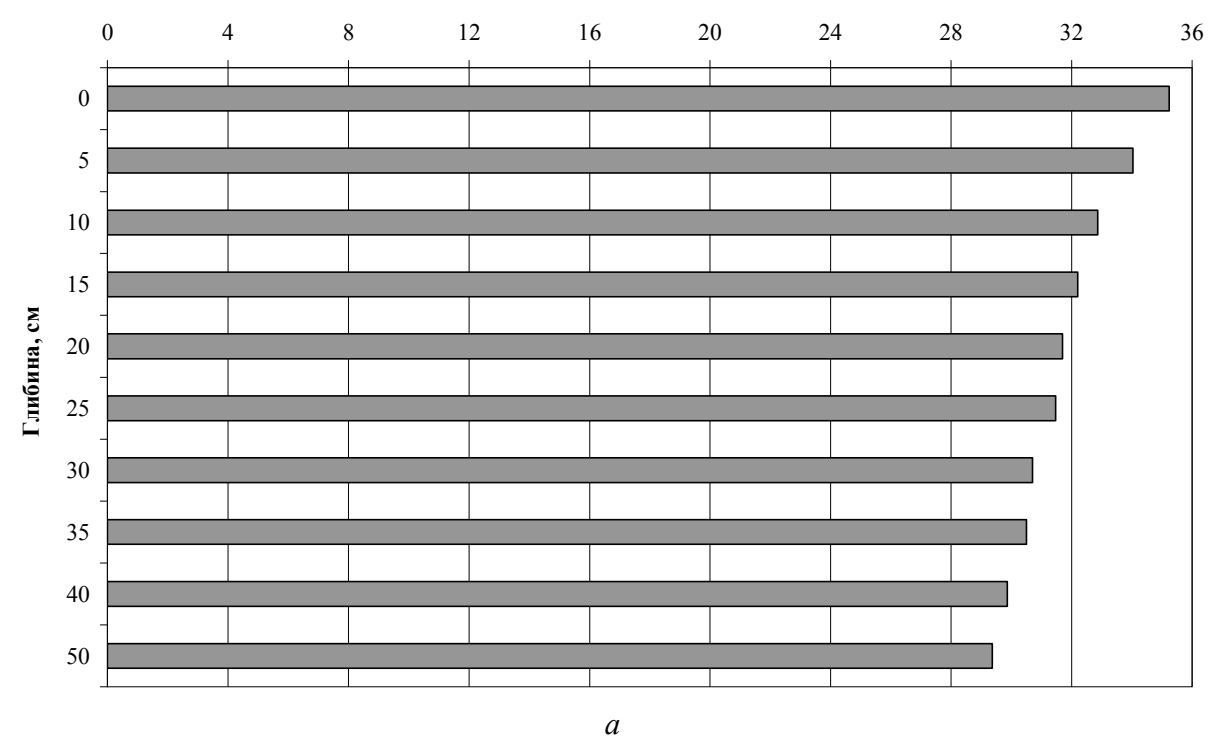

Температура, ${ }^{\circ} \mathrm{C}$

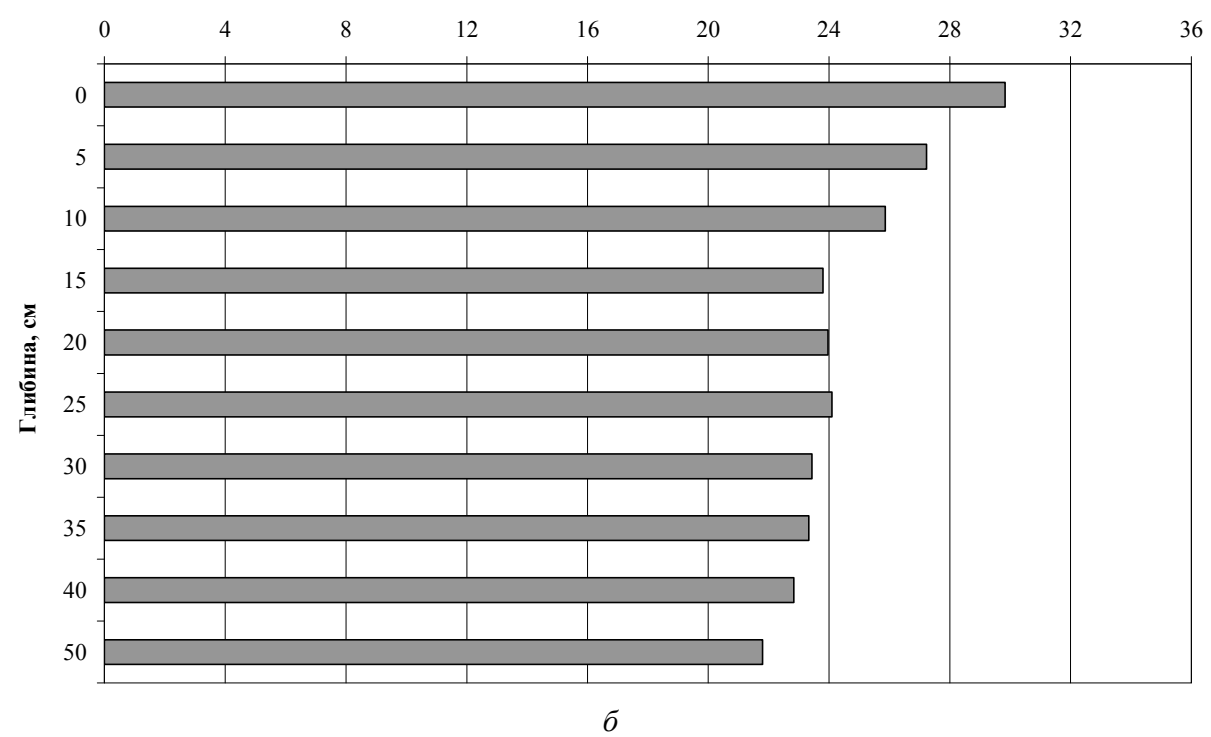

Температура, ${ }^{\circ} \mathrm{C}$

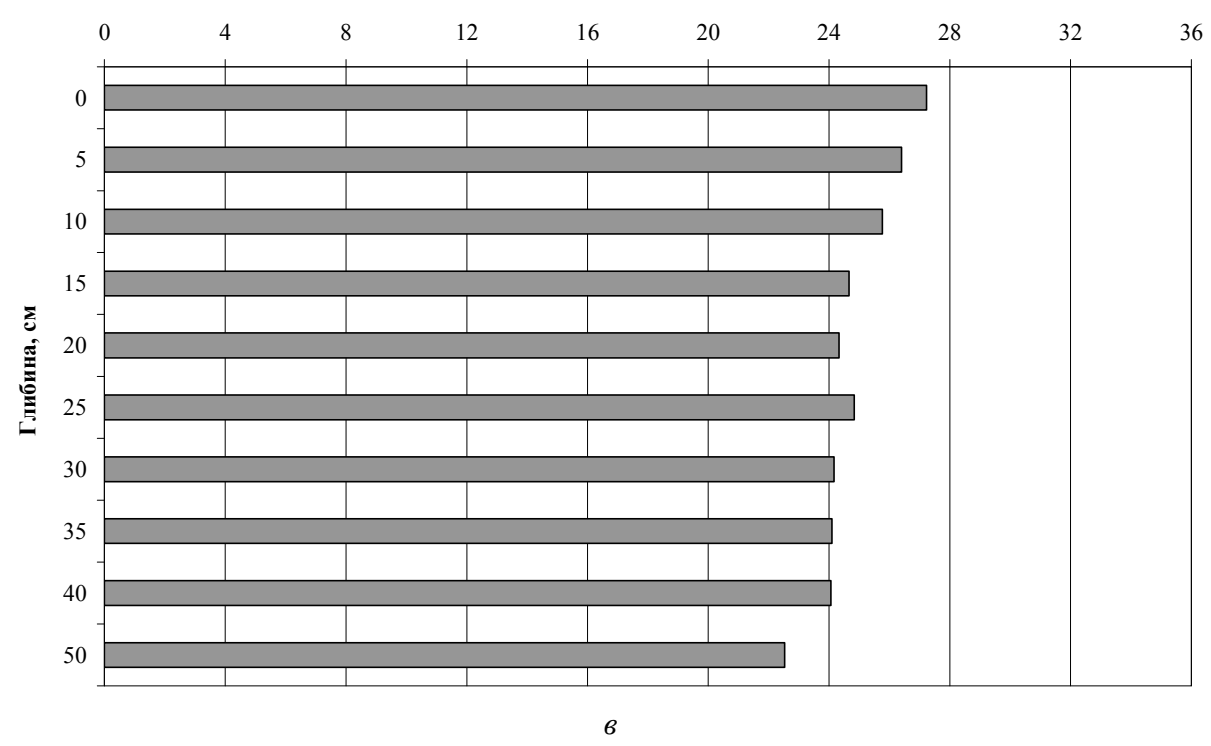

Рис. 1. Температурні показники досліджуваних грунтів на глибині від 0 до 50 см: $a$ - чорноземи звичайні; $\sigma$ - грунти під робінієвим насадженням; в - грунти під дубовим насадженням 
Таблиця 2

Теплофізичні властивості досліджуваних грунтів

\begin{tabular}{|c|c|c|c|}
\hline $\begin{array}{c}\text { Генетичний } \\
\text { горизонт }\end{array}$ & Температуропровідність, $10^{-7} \mathrm{~m}^{2} / \mathrm{c}$ & 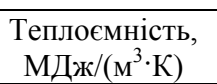 & $\begin{array}{c}\text { Теплопровідність, } \\
\text { Дж/(м'c·K) }\end{array}$ \\
\hline \multicolumn{4}{|c|}{ Пробна площа 1 - зональний чорнозем звичайний } \\
\hline Hop & $5,859 \pm 0,512$ & $1,416 \pm 0,071$ & $0,805 \pm 0,085$ \\
\hline $\mathrm{H}_{1}$ & $6,063 \pm 0,384$ & $1,357 \pm 0,077$ & $0,798 \pm 0,057$ \\
\hline $\mathrm{H}_{2}$ & $6,698 \pm 0,164$ & $1,364 \pm 0,024$ & $0,879 \pm 0,027$ \\
\hline $\mathrm{HPk}$ & $6,462 \pm 0,163$ & $1,299 \pm 0,009$ & $0,811 \pm 0,019$ \\
\hline $\mathrm{Pk}$ & $6,456 \pm 0,272$ & $1,306 \pm 0,026$ & $0,815 \pm 0,029$ \\
\hline \multicolumn{4}{|c|}{ Пробна площа 2 - чорнозем звичайний лісопокращений під насадженням Robinia pseudoacacia L. } \\
\hline $\mathrm{H}_{1}$ & $7,222 \pm 0,536$ & $1,342 \pm 0,067$ & $0,933 \pm 0,065$ \\
\hline $\mathrm{H}_{2}$ & $7,519 \pm 0,611$ & $1,338 \pm 0,056$ & $0,969 \pm 0,112$ \\
\hline $\mathrm{Hp}$ & $7,328 \pm 0,311$ & $1,404 \pm 0,080$ & $0,980 \pm 0,040$ \\
\hline Phk & $7,333 \pm 0,244$ & $1,384 \pm 0,012$ & $0,969 \pm 0,019$ \\
\hline $\mathrm{Pk}$ & $7,300 \pm 0,603$ & $1,391 \pm 0,026$ & $0,974 \pm 0,049$ \\
\hline \multicolumn{4}{|c|}{ Пробна площа 3 - чорнозем звичайний лісопокращений під насадженням Quercus robur L. } \\
\hline $\mathrm{H}_{1}$ & $6,840 \pm 0,324$ & $1,208 \pm 0,028$ & $0,792 \pm 0,028$ \\
\hline $\mathrm{H}_{2}$ & $6,737 \pm 0,285$ & $1,236 \pm 0,021$ & $0,801 \pm 0,037$ \\
\hline $\mathrm{Hp}$ & $6,739 \pm 0,587$ & $1,263 \pm 0,048$ & $0,815 \pm 0,041$ \\
\hline Phk & $6,810 \pm 0,117$ & $1,245 \pm 0,045$ & $0,818 \pm 0,020$ \\
\hline $\mathrm{Pk}$ & $6,834 \pm 0,281$ & $1,253 \pm 0,029$ & $0,808 \pm 0,031$ \\
\hline
\end{tabular}

$\left.7,340 \times 10^{-7} \mathrm{~m}^{2} / \mathrm{c}\right)$, а чорнозем звичайний - мінімальними (середнс значення за трьома горизонтами $-6,207 \times 10^{-7} \mathrm{~m}^{2} / \mathrm{c}$, за грунтовим профілем $-6,308 \times 10^{-7} \mathrm{~m}^{2} / \mathrm{c}$ ). Грунт під дубовим насадженням займає проміжне значення за цим показником.

Чорнозем звичайний відрізняється максимальними величинами теплоємності (середнє значення за трьома горизонтами - 1,379 МДж/( $\left.\mathrm{M}^{3} \cdot \mathrm{K}\right)$, за грунтовим профілем -

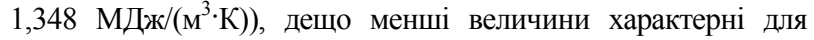
грунту під робінієвим насадженням. Мінімальні значення теплоємності характерні для грунту дубового насадження

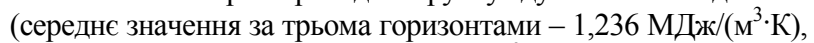
за грунтовим профілем - 1,241 МДж/( $\left.\mathrm{m}^{3} \cdot \mathrm{K}\right)$ ).

Грунт під робінієвим насадженням різко відрізняється максимальними значеннями теплопровідності (середнє значення за трьома горизонтами - 0,961 Дж/(м'c·K), за грунтовим профілем - 0,965 Дж/(м'c·K)) порівняно 3 чорноземом звичайним та грунтом під насадженням дубу.

Порівняння отриманих фактичних результатів зі зробленими припущеннями показало дуже малий відсоток збігів - для кожного грунту з трьох прогнозованих показників теплофізичних властивостей грунтів відносно порівнювальним 3 фактичними результатами виявився лише один.

\section{Висновки}

У результаті виконаних досліджень було встановлено, що деревостан робінієвого насадження зменшив температуру повітря на $4,5{ }^{\circ} \mathrm{C}$, дубового - на $9,4{ }^{\circ} \mathrm{C}$ порівняно з відкритою місцевістю. Максимальну температуру поверхні грунту виявлено в чорноземі звичайному. Вплив робінієвого насадження проявився у вигляді зменшення температури поверхні грунту на $5,4{ }^{\circ} \mathrm{C}$, дубового - на $8,0^{\circ} \mathrm{C}$. Максимальна температура грунту на глибині 50 см також виявлена в чорноземі звичайному. На такій самій глибині грунт під робінісвим насадженням виявився на $7,6^{\circ} \mathrm{C}$, під дубовим - на $6,9{ }^{\circ} \mathrm{C}$ холоднішим. За середньою температурою 50-сантиметрового шару серед усіх досліджуваних грунтів виділяється чорнозем звичайний, грунти під насадженнями за цим показником майже не відрізняються. Найменша різниця між температурою повітря та середньою температурою шару грунту 0-50 см виявилася в грунті під дубовим насадженням, найбільша - у грунті під робінієвим насадженням. Найменшу різницю між температурою поверхні грунту та на глибині 50 см виявлено в грунті під дубовим насадженням, а найбільшу - у грунті під робінієвим насадженням.
На основі аналізу отриманих результатів було зроблено припущення щодо термічних особливостей верхніх горизонтів, які входять до інтервалу глибин $0-50 \mathrm{~cm}$, кожного 3 трьох досліджуваних грунтів. Фактичне дослідження теплофізичних властивостей підтвердило правильність припущення лише щодо одного 3 трьох показників для кожного 3 досліджуваних грунтів. Це свідчить про значну обмеженість прогнозування теплофізичних показників грунтів, які базуються лише на вимірюванні їх температури.

Вплив робінієвого насадження на теплофізичні властивості чорноземів звичайних проявляється в збільшенні їх температуропровідності та теплопровідності, а також зменшенні теплоємності. Вплив дубового насадження характеризується зростанням температуропровідності та теплоємності, а також зниженням теплопровідності чорноземів звичайних.

\section{References}

Abu-Hamdeh, N. H. (2003). Thermal properties of soils as affected by density and water content. Biosystems Engineering, 86(1), 97-102. DOI: 10.1016/S1537-5110(03)00112-0.

Abu-Hamdeh, N. H., Reeder, R. C. (2000). Soil thermal conductivity: Effects of density, moisture, salt concentration, and organic matter. Soil Science Society of America Journal, 64(4), 1285-1290. DOI: 10.2136/sssaj2000.6441285x.

Bachmann, J., Horton, R., Ren, T., Van Der Ploeg, R. R. (2001). Comparison of the thermal properties of four wettable and four water-repellent soils. Soil Science Society of America Journal, 65(6), 1675-1679. DOI: 10.2136/sssaj2001.1675.

Belgard, A. L. (1971). Stepnoe lesovedenie [Steppe forestry]. Forestry industry, Moscow (in Russian).

Bristow, K. L., Kluitenberg, G. J., Horton, R. (1994). Measurement of soil thermal properties with a dual-probe heat-pulse technique. Soil Science Society of America Journal, 58(5), 1288-1294. DOI: 10.2136/sssaj1994.03615995005800050002x..

Dimo, V. N. (1972). Teplovoy rezhim pochv SSSR [Thermal regime of the USSR soils]. Kolos, Moscow (in Russian).

Gorban, V. A. (2006). Fizychnyy stan gruntiv yak ekolohichnyy faktor [Soils physical condition as ecological factor]. Gruntoznavstvo, 7(3-4), 102-111 (in Ukrainian).

Gorban, V. A., Gorban, A. A. (2007). Issledovanie teplofizicheskikh svoistv pochvy metodom impulsnogo nagreva [Investigation of the thermalphysic soil properties with the help of an impulse heating method]. Gruntoznavstvo, 8(3-4), 95-99 (in Russian). 
Hrytsan, Yu. I. (2000). Ekolohichni osnovy peretvoryuyuchoho vplyvu lisovoyi roslynnosti na stepove seredovyshche [Ecological bases of the transformative influence of forest vegetation on the steppe environment]. Dnipropetrovsk (in Ukrainian)

Ivanko, I. A. (2016). Ekolohichna rol svitlovoyi struktury u formuvanni shtuchnykh lisovykh nasadzhen u stepoviy zoni Ukrayiny [Ecological role of light structure in the formation of artificial forest plantations in the steppe zone of Ukraine]. Bioheotsenolohichni doslidzhennya lisiv stepovoyi zony Ukrayiny. Svidler A. L., Dnipro. 155-171 (in Ukrainian).

Lukyashchenko, K. I., Arkhangelskaya, T. A. (2018). Modelirovaniye temperaturoprovodnosti pochv razlichnogo granulometricheskogo sostava [Modeling the thermal diffusivity of soils of different grain size distribution]. Eurasian Soil Science, 2, 179-186 (in Russian). DOI: 10.7868/S0032180X18020053.

Makarova, G. P. (1987). O vliyanii vlazhnosti na teplofizicheskiye svoystva temno-serykh lesnykh erodirovannykh pochv [On the effect of humidity on the thermophysical properties of dark gray forest eroded soils] Erodirovannyye pochvy i effektivnost pochvozashchitnykh meropriyatiy. Moscow, 65-70 (in Russian).

Ochsner, T. E., Horton, R., Ren, T. (2001). A new perspective on soil thermal properties. Soil Science Society of America Journal, 65(6), 1641-1647. DOI: 10.2136/sssaj2001.1641.

Sozin, Yu. A. (1990). Opredeleniye teplofizicheskikh svoystv pochvy metodom impul'snogo nagreva [Determination of the thermophysical properties of the soil by the method of pulsed heating]. Antropogennyye vozdeystviya na lesnyye ekosistemy stepnoy zony. Dnepropetrovsk, 95-101 (in Russian).

Teorii i metody fiziki pochv (2007) [Theories and techniques of soil physics]. Ed. E. V. Shein, L. O. Karpachevskij. Moscow (in Russian).

Travleyev, A. P., Belova, N. A. (2008). Les kak faktor pochvoobrazovaniya [Forest as a factor in soil formation]. Gruntoznavstvo, 9(3-4), 6-26 (in Russian).

Vadyunina, A. F., Korchagina, Z. A. (1986). Metody issledovaniia fizicheskikh svojstv pochvy [Methods of study of the physical properties of soil]. Moscow (in Russian). 